解説

\title{
毛紡メタリックカード使用に関する 二,三の実験について
}

大倍綃績株式会社

LI

勝

"

正 垣

大

$\rightarrow$

\section{1.まえがき}

炤和 30 年 3 月本会「メタリックワイヤに関する講潰 懇談会」に扣いてわが社の「ガーネットワイヤ梳毛力 一ドについて」発表したが，その際はシリンダ多びドッ ファの浶卷の 1 七ット ( 8 連) と, 面卷の 1 セット( 9 連）のそれぞれの機械的条件，運転条件並びに品質面の 工場実験資料の比較検討について詳細発表し，その等舆 面淃の有利性を实証すると共に、プロクタメタリック カードの試験例のデータとも合せ考えて, 梳毛用針布力 一ドとの比較を考察して, 梳毛紡續にメタリックカー ドが今後㕕く使用されるであるうし，また使用されるべ きではないかということを詰論とした。

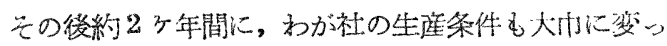
て来たが，この間メタリックカードの方は，例えば溝 巻の 1 Łットのデリベリドッファを面巻に改造し、ま た運転条件すなわら梳針の条件，周速比の開題，ゲージ の調整，供給绵料の䥣及び状態の調節等についても，種 く尖驗を重小て来たが，これらに関しては，残念ながら いまだ具体的に発表の時期に至っていない。

したがって生産面のことについては，原料供給嚳增加 の開題についてのみ，現在迄の結論を発表するにとどめ 今回は土として，かーディング作用の中，各ローラの回 転による流体的の闍題について、メタリックワイヤを

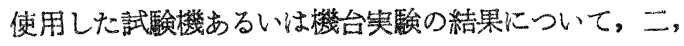
三の中闒発表をする。

\section{2. カード生産增加の問題について}

カード機が良好なる条件でれットされ，合理的速度で 連転されれば最大生産量が得られるわけでそその中でシ リンダの速度は最す重姴であり、これに伴って他のすべ てのローラに影響を与えることは周知の通りである。

一般にはシリンダ速度は繊細羊毛程速く，粗硬な羊毛 程痋くするのが英例である。

また昗好なカーディング作用のためには，所罗生座舅
を洘渨した籍井內で，軗く原料を供給することすなわ ら梳針に刘し，過乘な繊維を供給しないことである。

これらはカード生産に和いて，考慮すべき事項である

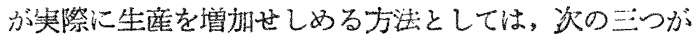
洘光られる。

(1) 機械全体をスピードアップする方法

（2）原料供給量を増加する方法くドッフォの增速を 含む)

(3)（1）と（2）を兼社合せた方法

この中 (1) 項の方法はわが社においては, 8 連及び 9 連の同期運転をとれぞれ採用している関係で，運転す 式そのるのを十分検討してかからねばならぬ闍題で, 今 すぐ採用でさない現状である。

したがってわが社で現在採用しているのは，(2)心 よる方法，すなわら給毛䀠を增加し，その增加率だけデ リベリドッファを增速するやりカである。

この際一番間題になるのは，説明するまでもなく、紡 出ウ土ブの品質はど5かすなわち繊維可れ, 開舒の不卜 分、ネップの増加等の点はどうであるかといらことであ る.

これらについて,シリンダ回転数は現状のままで,源 料供給量を，紡出スライバ番手が $14 \mathrm{~g} / \mathrm{m}$ (结座舅約 $35 \mathrm{lb} / \mathrm{hr}$ ) から $20 \mathrm{~g} / \mathrm{m}$ になる迄次第に增加せしめた場 合のくデリベリドッファの回転数は $8 \sim 11$ r.p.m. K変 える) 幾つかの実験結果をあとめてみると次のような結 訟になる。

1) 原料供紿量の增加に伴い,ネッブ,ノイル共に堌 加の傾向を示し, 從来比して 30〜40\%增で, ノル は彷来より $0.5 \%$ 程度增加する。

2) 64７0's 原料に就いては，供給撂を28\%增程度 に押えるとネップ，ノイル共に安定した結果を示す。

3) ファンシのない場合, デリベリドッファの回転 数をある限度以上にしてる，ウェブの状態は良くならな いか変らない。

4)ファンシを取り付けた場合，3）の場合と同じ 


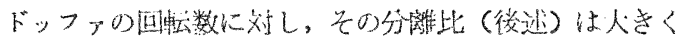
なる。したがって給毛量の增加刘して，品筫面の安定 度は3) の垭合より大きいといえる。

5) デリベリドッファの速度增加はノイルにほとん

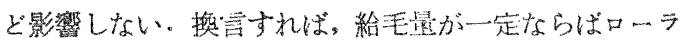
の避速によるウェブの品罂は，ほとんど変らないと考え てよい.

以上の結舆，メタリックカードに括いてはかなり給 毛量を增加してむ，カ一ドの条珄を適芯せしめることに

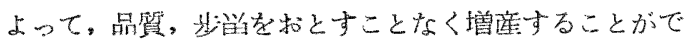
きるものい光る。

わが补メタリックカードに执いては 64一70's 原料の 埸合, 綃Hスライバ番手が $18 \mathrm{~g} / \mathrm{m}$ 位で生座翼は $45 \mathrm{lb} /$

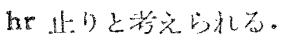

\section{3. カーディング作用の一, 二について}

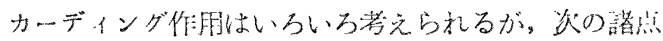
から洘察することが比挍湖会理的である。すなわち

(1) 梳針の機栈的倠用

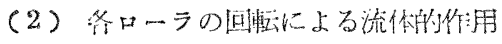

(3) 瀻維震の分柏状熊

(4) 紡出スライバの状熊

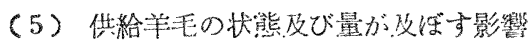

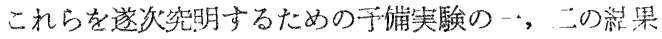
を銭告する。

(a) ローラの分䆶比について

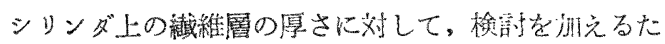
めに行った笑験である。

カ一ディング作用に扎いて、緎維を運んで来た一方の 梳針に対して，他方の梳針が作成するとき，これを機械 的作用のみで考えた境合，理論的にはそれぶ受缶作用な

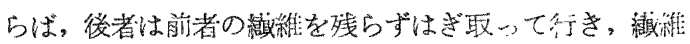
の浮掦作用ならば，全く受取らないはずでする。しかし 些際のカーディング作用に批いては，一部はそのまま残 り，一部ははぎ取られて行く状態でむる。

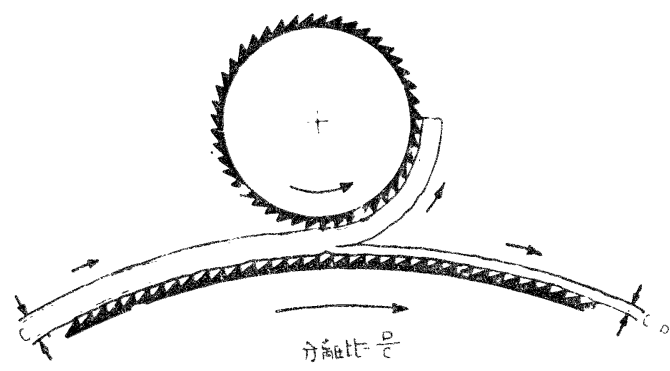

(第; 1 汹)

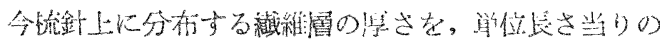

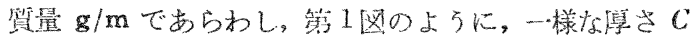

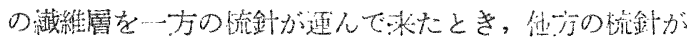

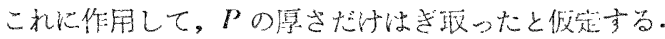

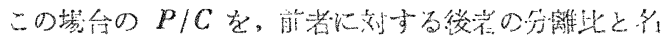
うおよ

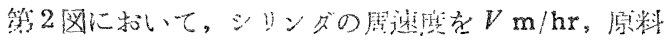

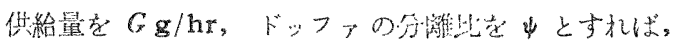

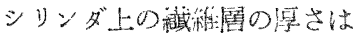

$$
\stackrel{G}{\psi V} \mathrm{~g} / \mathrm{m}
$$

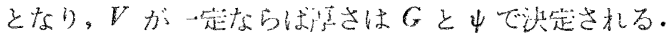

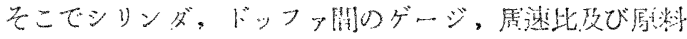

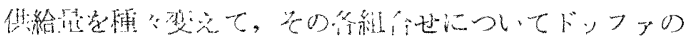

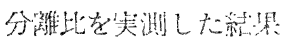

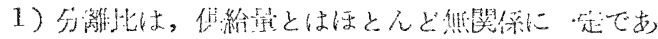
z

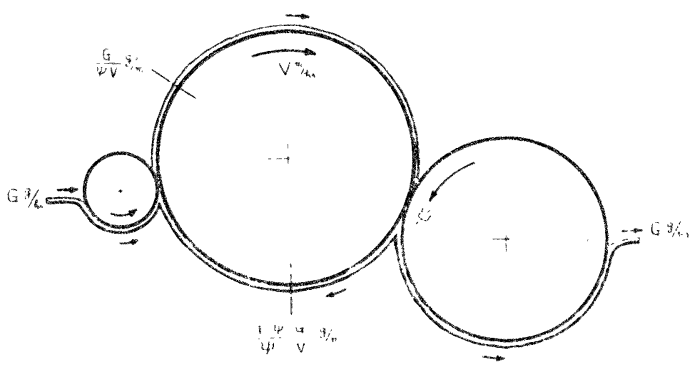

(第 2 叫)

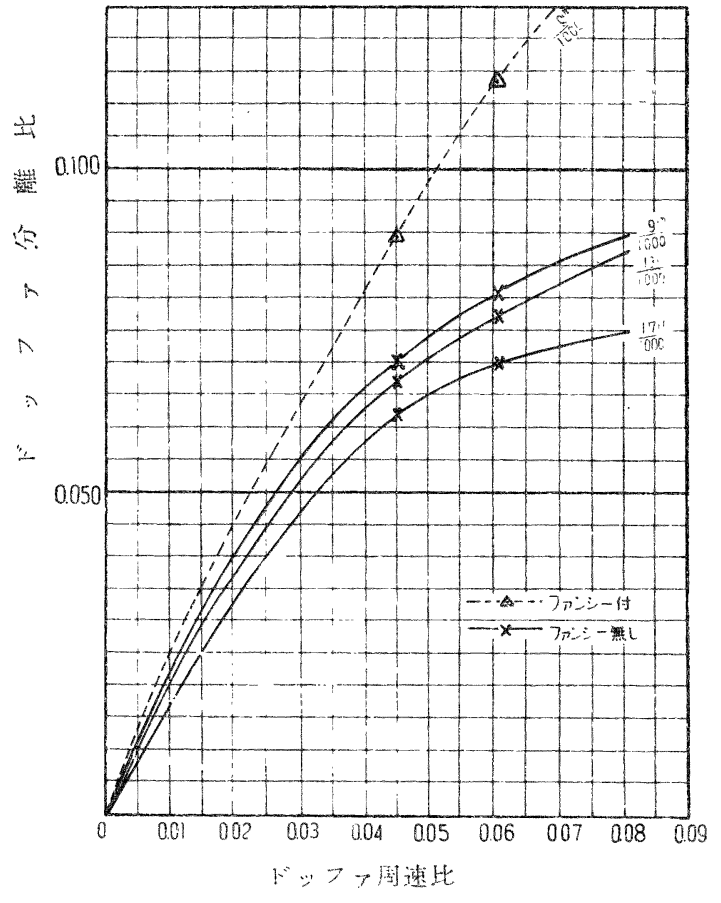

(第 3 [四) 
2）ゲージと周速比とにしたがって変化し，との関係 は第3因のようになる

といらことが判明した。

第 3 区の实線で示したのはファンシなし, 点線の方は ファンシ付の結果である.

これらの結果をもとにして, 給毛量を增して生産量を 增加しようとする境合，ある一定の供給量が定められた 場合、ドッファのゲージを狹めるほどあるいはドッフ アの周速を高めるほど, シリンダ上の繊維蹱は薄くなり 品質面の安定度を增すことになるということが推定でき る。

しかしながら、メタリックワイヤ卷上りローラの精 度, カード機全体の报動度合，精度等からゲージにも自 ら限度がありまたドッファの回転数もとの直径を一定 とすると、ドッファコームとの回転比の点から、これ また限界が出てくる方けである。

これらの兼合いをどういう条件にして，品質を向上せ しめるかということは，カード機担当技術都として最も 苦心を要する事項である。

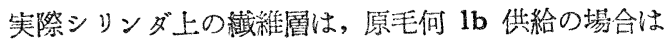
何 $\mathrm{mm}$ になるか，またとれがどのように变化するるの であるか，とい5点については目下実験中である。

(b) シリンダ上の風速分布について この実験はシリンダ上の纎維に与兄る流体的影響を,
根本的に梌討するために行っている榙笑験の一つですっ て，その第一段階のものである。むちろん（a) 項にも 関連するものである。

実験に便用しているメタリックカードり条件㑐。次 の通りである。

（1）ローラの配列は第 5 因参照（沾 60 in 1 山力ー ド)

(2) スイフトシリンダ直徍 $1235 \mathrm{~mm}, 158$ r.p.m. デリベリドッフ 遍径 $856 \mathrm{~mm}, 6$ r.p.m.

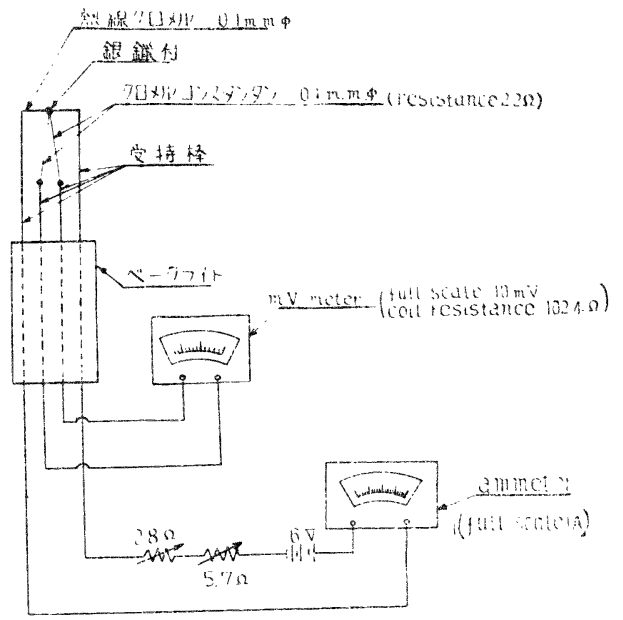

（第４欧）熟霞対風速計（Themocouple anemometer 結線四)

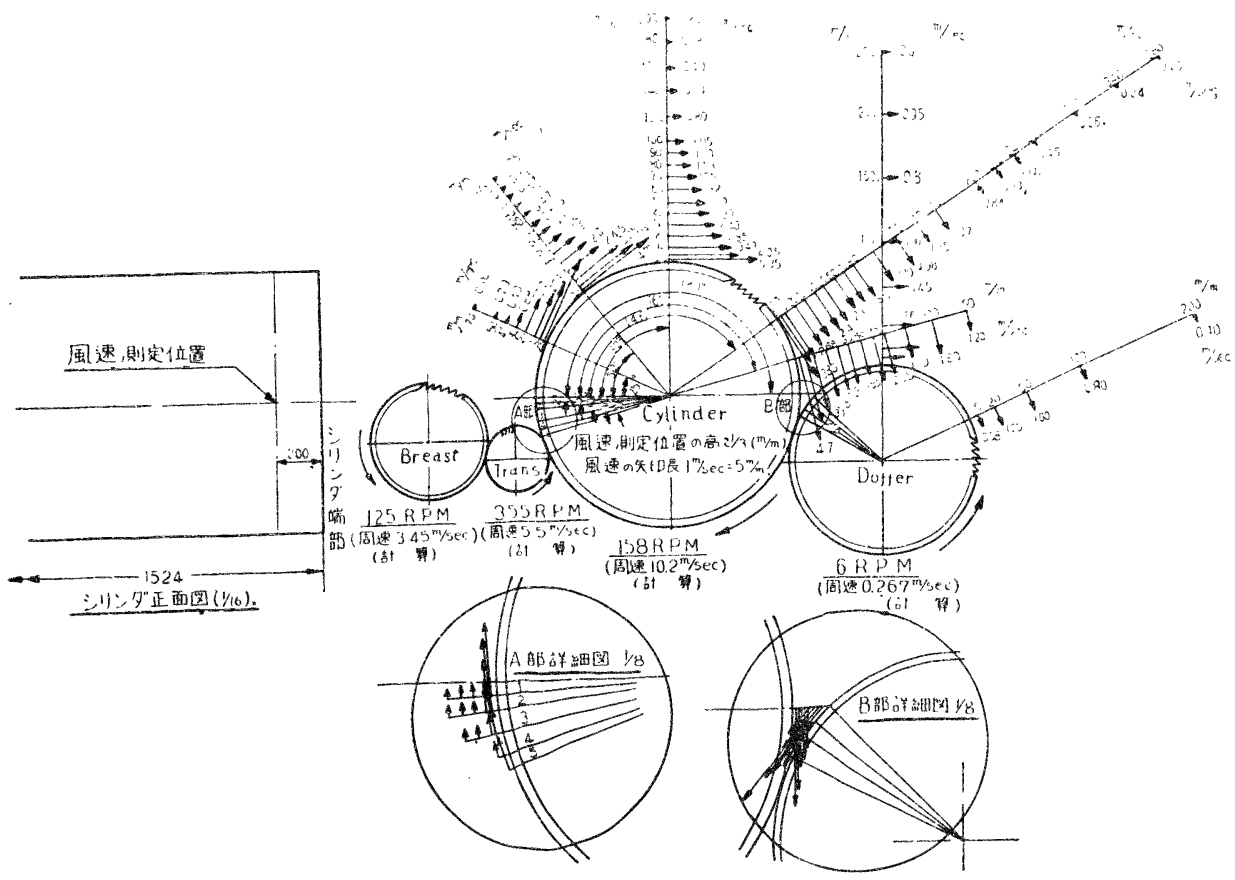

（第 5 図）メタリックカードのシリンダ上の風速分布状態 (Worker Stripperなし) 长度 (1/16) 
（3）シリンダ, ドッファ共に面䅈にして，その針頭 密度は

$$
\begin{aligned}
& \text { シリンダ } 254 / \mathrm{in}^{2}(11 \mu / \mathrm{in}, 0.81 \mathrm{t}, 32 \text { 's }) \\
& \text { ドッファ } 298 / \mathrm{in}^{2}\left(14 \mu / \mathrm{in}, 1.00 \mathrm{t}, 26^{\prime} \mathrm{s}\right)
\end{aligned}
$$

（4）シリンダ上のウホーカ,ストリッパは全部取外 ఫ

[注】〕空內空気の動摇の影響をできるだけ少なくす るために，笑験機の周囲を隱蔽した

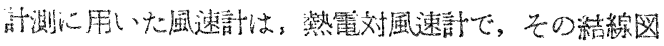
第4细江示吉。

第 5 四は風速の人きさを机ぞれ計測の位置で，矩印 り長さで四示したものであち。

その結果汇ついて

1)シリンダ表缅から㒕れるにしたがって，風速は次 第に洛セでての分布形状は，㸚物線の形をなしているこ レがわかる。

2）その人きさの畐度は、シリンダの回転方间に特い て、ドッファに近づくにしたがって薄くなる。

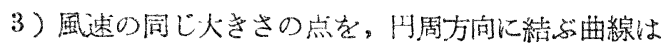
インボリュー!型とい党る。

4) シリンダ上 $120^{\circ}$ 位迄の風の流線は, 大体図示矢 印の向き化一致するが，それよりドッファに近づくにし たがって、ドッファの回転による流線と、ドッファが一 つの壁としての抵抗作用をする関係等が相対的作作用し て, 流線は複維に乱机る。(この)部分の乱れ, 变化等に
ついては，目下実験継続中である)

5)したがって図示の $146^{\circ}$ より前の位置の矢印は， 单汇風速の大きさを示すにとどまる。

6) シリンダ表面から $2.5 \mathrm{~mm}$ 離れた位置の風速は, どの棓測部分に招いても，大体諳算上の周速の約半分に 落ちている。

7)この計測結果のみでは，空気の境界屬を判定する ことは困難である。

第 6 図は,シリンダ側面水平軸汇対してっトランス ポ

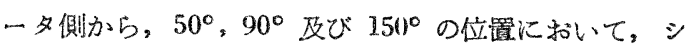
リンダ表面から $5 ， 20$ 及び $40 \mathrm{~mm}$ 離れた部分をそれ ぞれ軸方向に計測した風速分布図である。

この結果について

1)シリンダの中央 (30 in の位置) から, 左右に擗 分けた実測値㤝，計測誤差程度にしか差が認められなか

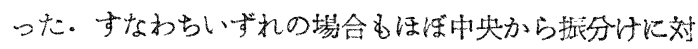
称形の風速分布になっている・（したがって図示は快央 加ら左右全(対称にした〉

2 )シリンダ表面から，同距離同位置に打ける風速を 第 5 図の場合と比較して見ると，いずれも第 6 図の計測 結果が低い值を示している。(この事実は再検討を要す る)

3) 軸方向におけを風速分布の波打ちは，いずれの境 合も大体同じ傾问をとっている。

4）シリンダ端部に和ける風速は，いずれも軸方向の

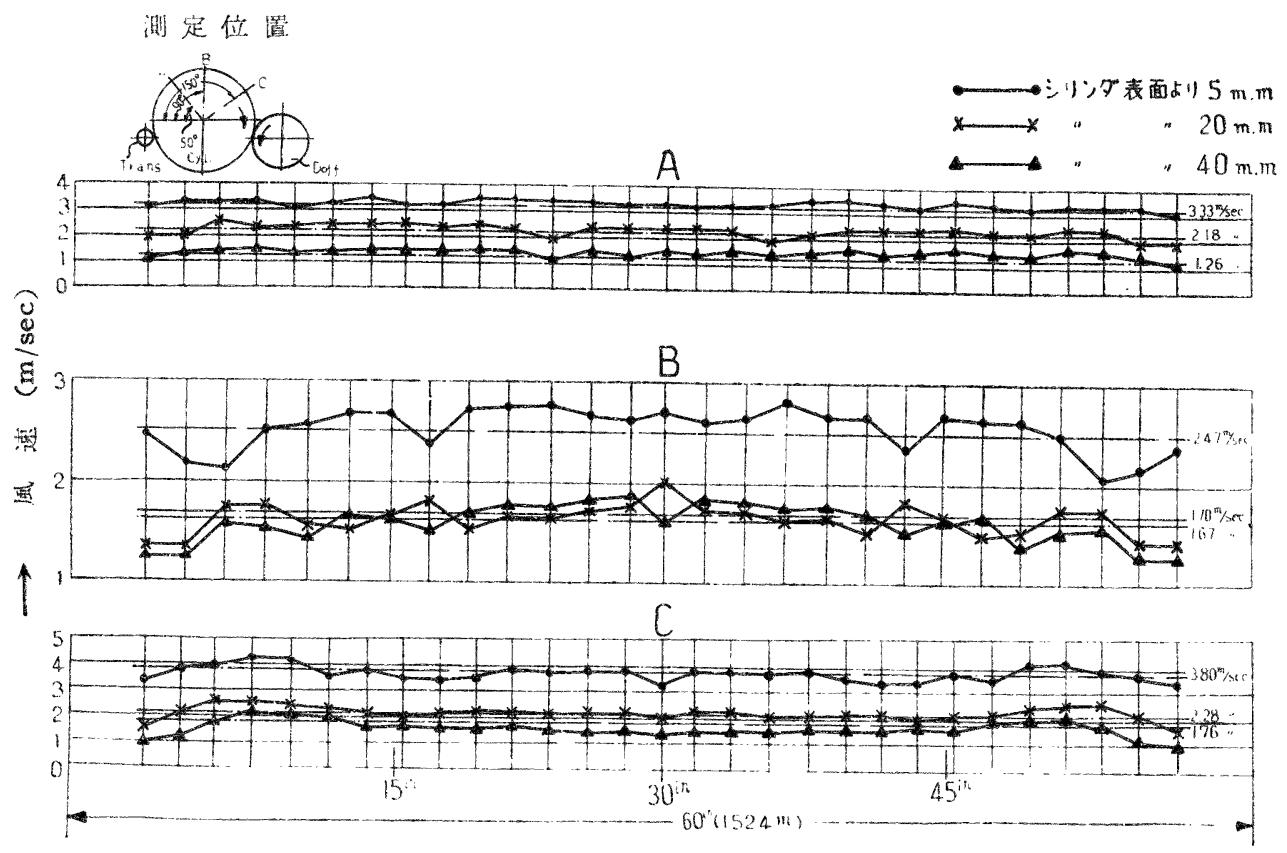

(第6 6 汹)メタリックカードシリン多軸方向の風速分布困 


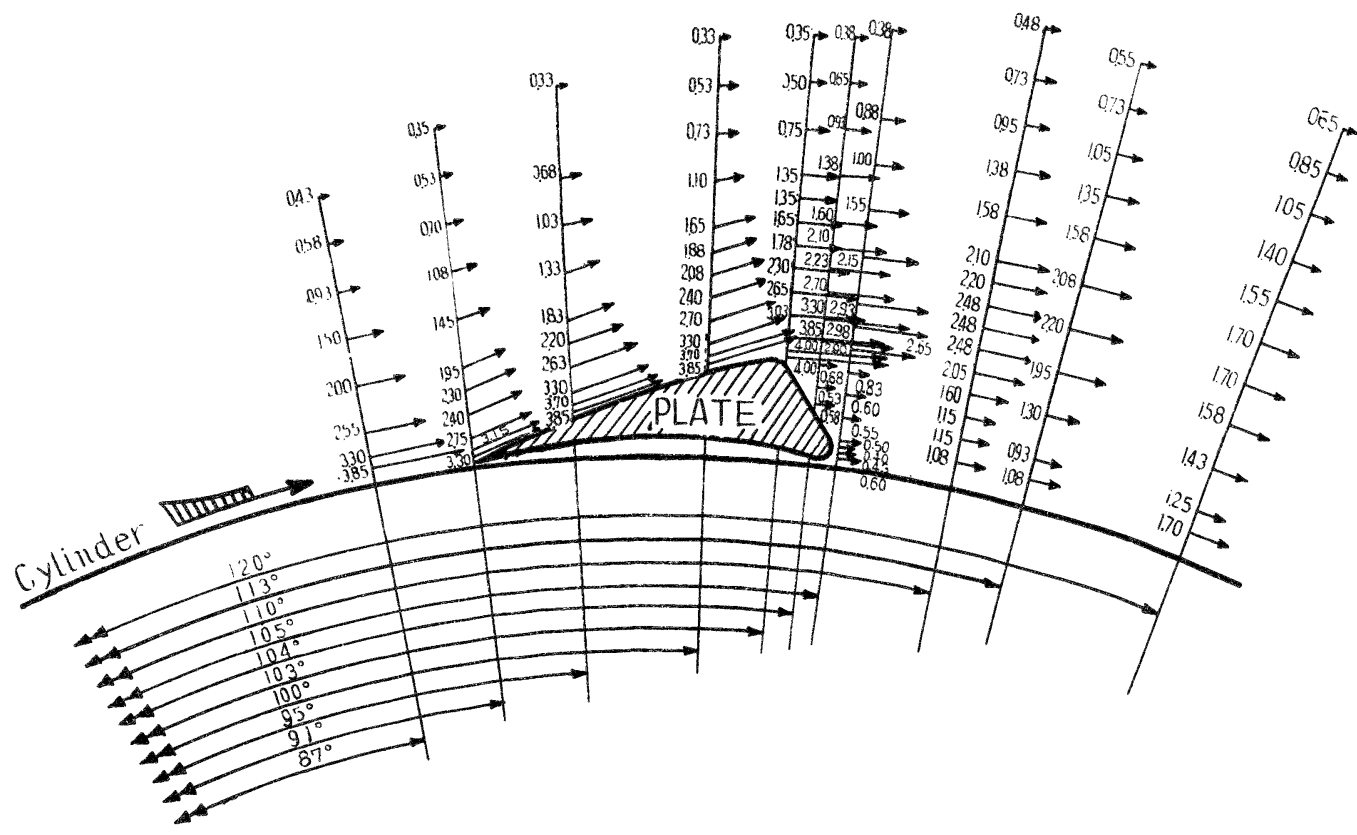

(第7区、メタリックカードシリンダ上の風速分布汹(プレート付)

風速 $1 \mathrm{~m} / \mathrm{sec}=5 \mathrm{~m} / \mathrm{m}$

平诗風速值よりもやや低い值を示している。

5) $50^{\circ}$ の位置に招いては, シリンダ表面から 5,20 及び $40 \mathrm{~mm}$ 離れた位置の平诗風速值の間隔はほぼ等し ᄂ.

6) $90^{\circ}$ の位置においては，40 mm つ場合と $20 \mathrm{~mm}$ の場合の平站風速值が非常に接近しているのが目立つ。

$5 \mathrm{~mm}$ の位置の平圴風速值が，第 5 四の場合に比べ て特に低い。

7) $150^{\circ}$ の位置においては, $40 \mathrm{~mm}$ の場含と $20 \mathrm{~mm}$

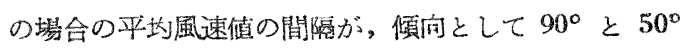
の場合の中關的である。

第 7 这は,ウォ一カの代りに, 断面刹楾形状のプレー トを，その先端が $90^{\circ}$ の位置になるよ5に取付けた場合 のそのプレート前後の風速分布が，との上うに变化する が示したものである。

その結果について

1) プレー?頂点までの風速分布の形状は，第5図の

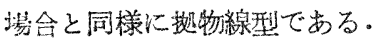

2）プレート前沁おいては，第5这の場合よりも減速 されている。

3)プンート表部に扣いては,やや堵速されて進む傾

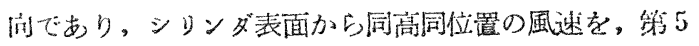
図の場合と比較して見ると，30 ５0\%増速されている ことになる。
4)プレート背部に扣いては著しく減速されている。

5）そのプレートによる減速の影響は，120〜140 付 近まで続くものと考えられる。

6) プレートよりドッファ側に利いては, シリンダ表 面からの高さによる風速差が，少なくなるのが特徴であ る.

次にメタリックワイヤと針布が，風速の大きさ江与 える影響を比較検討するために，再機の他の条件を大体 一致せしめて、針布カードについて風速分布を棓測し た。

実験に使用した針布ローラ，カードの条件は次の通り である。

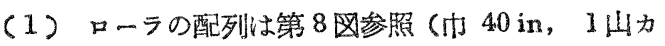
$\left.-r^{*}\right)$

(2) スイフトシシンダ直径 $1293 \mathrm{~mm}, 135 \mathrm{r.p.m}$. デリベリ、ドッファ值径 $705 \mathrm{~mm}, 8$ r.p.m.

（3）シリンダ，ドッファ共に針布帣にして, その針 頭密度は

シリンダ $424 / \mathrm{in}^{2}$ (仁式針布番手 18\#)

ドッフォ468/in2(仏式針布番手 20甘)

(4) シリンダ上のウォ一カ反呚ストリッパは全部取。 外す。

第8昸は針布カードのシリンダ上風速分布状態を示 し，第 5 図と比較し得るものである。 
その絬果について

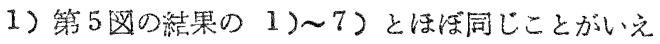
๘.

2）四周速度の計算值が，メタリックカードの㙏台 よりも約 $1 \mathrm{~m} / \mathrm{sec}$ 小さくなっているが，風速の大きさ
が大体同じ値であることは、針布の方が針頭密度の多い ことによるものと考觉られる。

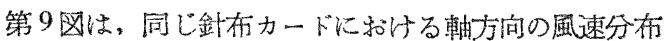
図で，第6図と比較し得るむのである。

メタリックカードの第 6 図の場合と比輍して，相迬

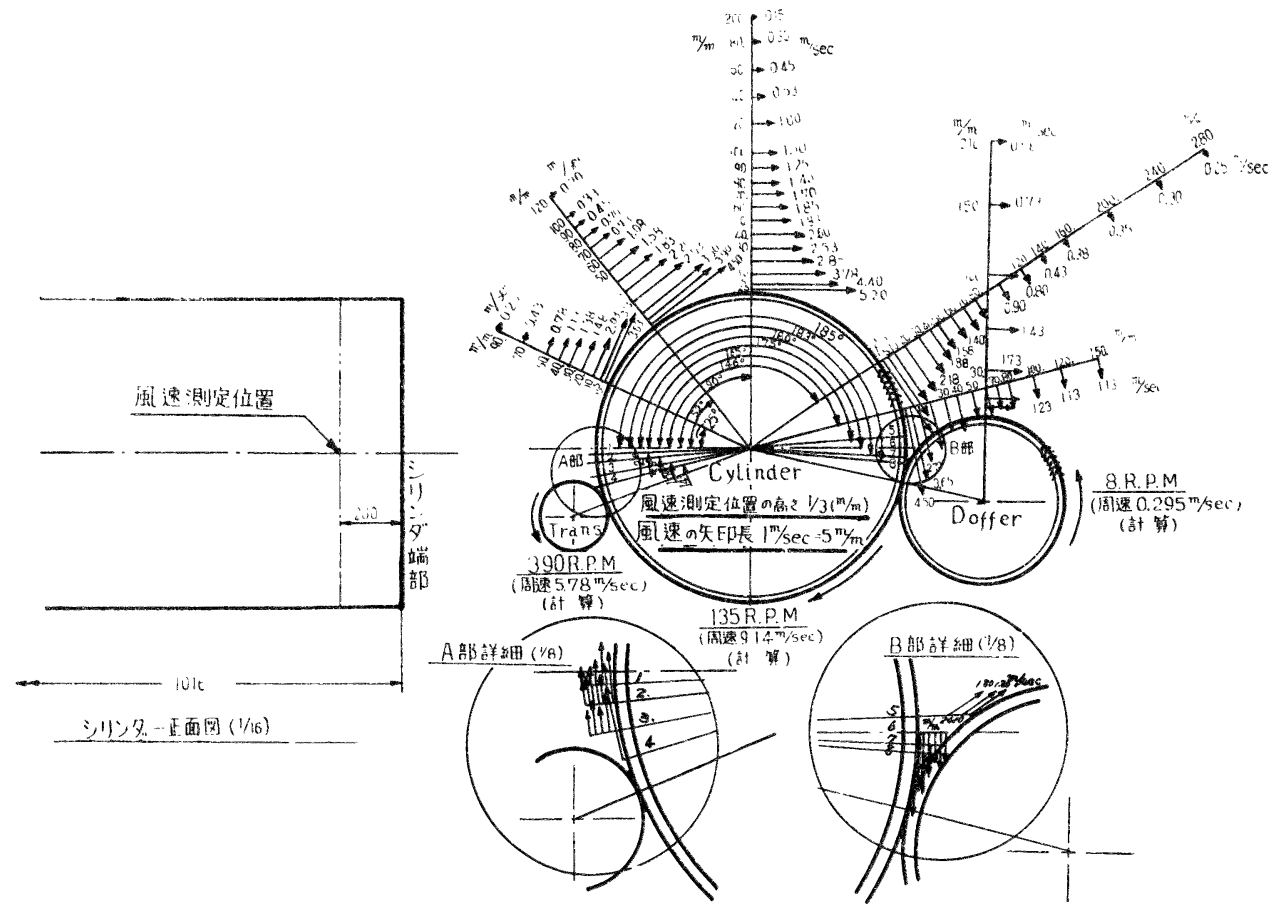

（第 8 図）針布カードのシリンダ上の風速分布状態（Worker Stripper なし） 尺度（1/16） 测定位置
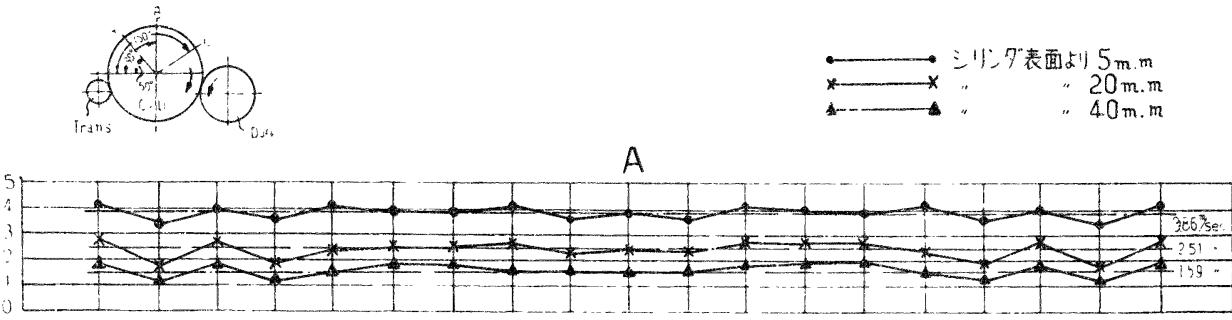

导

B

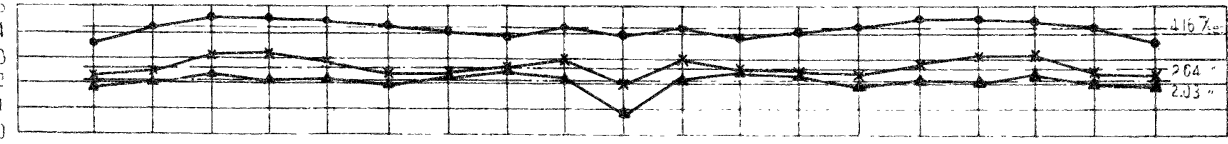

通

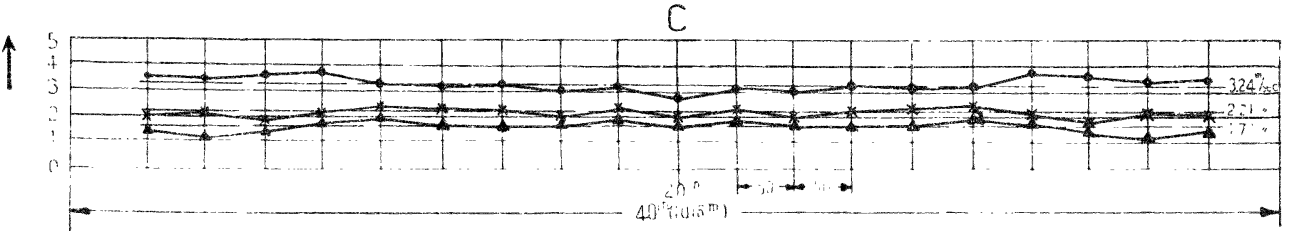

(第9四) 針布カードシリンダ軸方向の風速分布困 
してい石傾间にある项目学挙げて兒ると

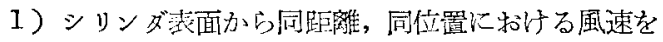

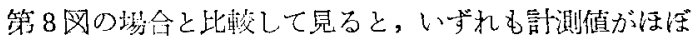
一致している。

2) メタリックカードの堨命に比して，いずれの場 合も風速の軸方向に拈ける擞打りがやや少ない。

3) シリンダ端部における風速は, メタリックカー ドにおいては下り気棟であるが，針布カードではすしつ 上り傾向になっている・

次にシリンダ上のウォーカ改びスリリッパを取外した 状態で原料を倛給して，シリンダ上の風过による繊維の

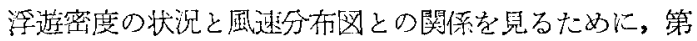

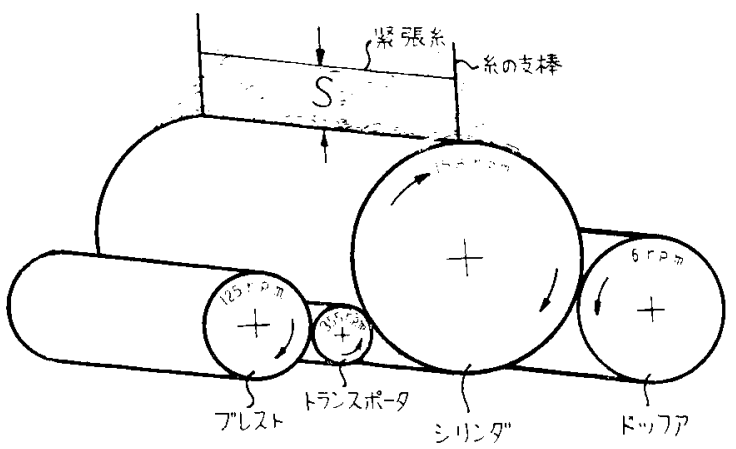

(第 10 四)
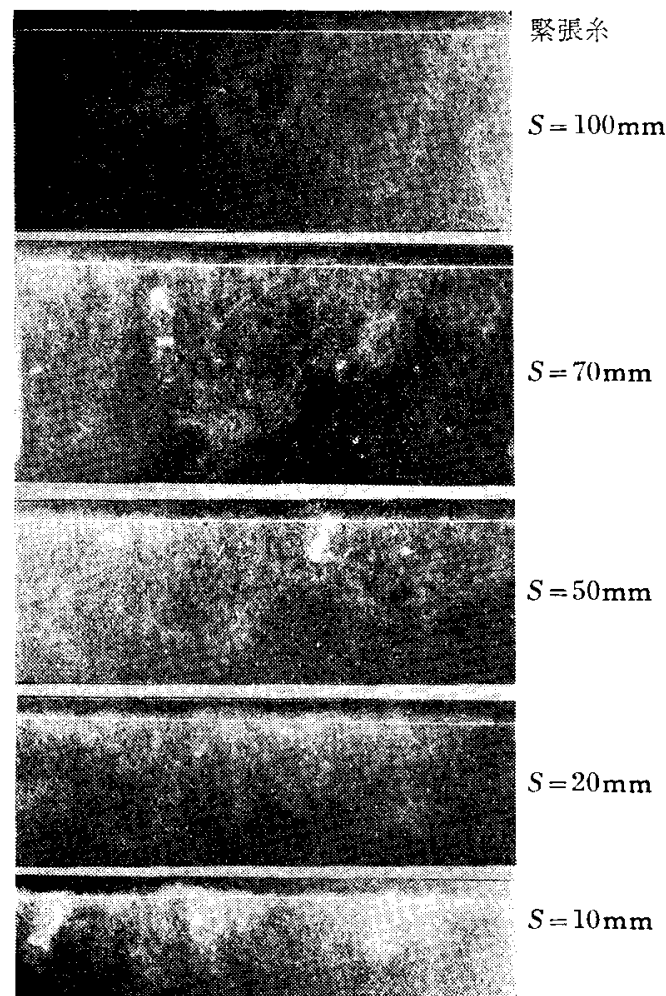

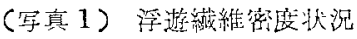

10为の状態で奏験した。

供給原料はフィードラチス上们に $1 \mathrm{~m}$ に当り

$1 \mathrm{lb}$ の投大量である。

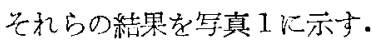

その結果について

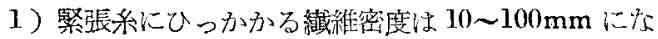
るにしたがって薄くなる。

2） $10 \mathrm{~mm}$ のところでは，開釷不师分のかた东引が ひっかが・

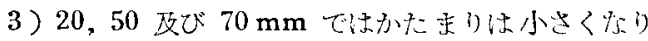
少胥い。

4） $100 \mathrm{~mm}$ では解毛されたもののみでむる。

5) $150 \mathrm{~mm}$ では，浮遊瀻維はわずかながら飛んでい るが，禾には全然かからない（写真撮影省略）

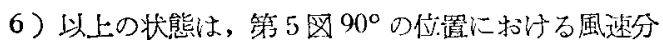
布状態の傾向と一致する。

7) 風速 $0.5 \mathrm{~m} / \mathrm{sec}$ 程度以下のところでは, 浮遊瀻 維は全く公內空気の動きに乗って，極く自然の状態をと る・すなわら瀻維の動きに方向性がなくなる。

(c) ドッファ, シリンダ間の受渡作用の予䜤実験に 小て

ドッファとシリンダ間の受渡作用に, 流体的の要素が どのような影響を与えているかの見通しをつけるために 行った。

垁験状態の写真撮影が困難なため，もっぱら「眼によ 碓察」によったものであることをあらかじめ的ことわ 1) しておく.

使用したカード機の条件は次の通りである。

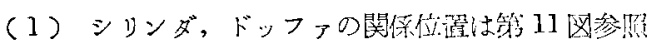
(i) 60 in)

(2) シリンダ直径 $30 \mathrm{in} \phi(762 \mathrm{~mm}), 150$ r.p.m. ドッファ直径 $24,1 / 2$ in $\phi(623 \mathrm{~mm}) \quad 7$ r.p.m.

(3) シリンダ,ドッファ共にメタリックワイヤの 面卷にしてその針斯密度は

シリンダ $168 / \mathrm{in}^{2}(8 \amalg / \mathrm{in}, 1.275 \mathrm{t})$

ドッファ $236 / \mathrm{in}^{2}(10 ! 4 / \mathrm{in}, 1.15 \mathrm{t})$

(4) シリンダ, ドッフォ間のゲージ 7/1000 in

以下拈べる実験の判定は，すべて前述したよ5に「眼 による钼察」によったものでここのため同時に 3 人の 眼で，同奏験を数回繰返して，てれらを総会して一応の 結論とした次第である。

（イ）伍実験その 1 (用部)

これはシリンダとドッフっの接点上側入口（第11罒

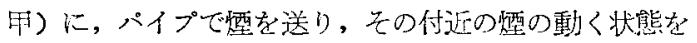
兒た実験である・

この際一番開題になったことは,㖶の種類である。 
数䀯の煙を使用した結果, 最も效果的であ ると教兄られるむのは，生上もぎを一屋夜位 乾して、これにマシン油を若干ふりかけ、そ れをいふした時の煙である。

第 11 四甲の上5に，䙳を実線知印の方向 に㟔てると

1) 煙は点線矢印の方向に分散して行く。

2) 煙はシリンダ表面から, $5 \sim 8 \mathrm{~mm}$ 位. (眼の観察)の厚さから中へは進まない。

3 ) シリンダ表面汇向ってからその大部分 のものは、ほぼドッファの中心方向に向5.(2)

4) (2)から (3) (4) 一と分れて進蚂。乞の量 は(3)(4共に添渒同じである。

5 ) シリンダ表面から, (1方向に進むる のもあり，可の方向に進むわずかなるのもあ るように見える。

6) 以上は第 5 四のこの部分の流線状況推定の 1 ヒン トにはなる。

\section{(ロ ) 哂実験その 2 (乙部)}

これは第11 因乙部について、シリンダ、ドッファ下 のピットの中において観察したもので,シリンダドッ ファ間の接点を出た付近の流体的現象を見るのが目的で 山る・

カード機の接点から下に位置する部分は，その前， 後, 哄部共に完全にトタン板で密閶し, 窒內空気の状態 が禋の動きに影響を与えないようにして、るっばらシり ンダ、ドッフォの回転によって生ずる流体的現象のみ が，䃌に作用するように考虑した。

L一M 䓅び N-O 線は，㖶源奖置いた位置を示与。 その結果について

1) $\mathrm{L}-\mathrm{M}$ 線上C点よりドッファ側では, 絰はすべて 上昇して、シリンダ,ドッファ閶の接点に向って進む.

2) C 点よりアンダ，アーシング側すなわち，B，A 点等から発した煙は, 知印のらに淔線的に上昇して, シリンダ面に近づくと,シリンダ回転方向すなふらなン ダケーシング內に吸い込李れて行く。

3) N-O 線上のE，D点より発した煙は，ドッフォ 面迄上界して，そこからドッファの回転方向上は逆にド ッファ面に沿って上舁し，やはりシリンダ，ドッファの 接点方向飞向亏。

4) $\mathrm{N}$-O 線上の F, G 点のものは,ドッファ面迄上 鼠して、をとはドッファ面にとって，回転方向に進行寸 る。

5) 以上の結果, 大体斜線內では,ドッファの回転に よる風速と方向飞打滕った負压が，生じているように見 える。

\section{(八) 極短繊維実験}

勿11图丙は，乙部の噴出状態を見るために，栖短㵶 維 (パー,ローラに付着した羊脂カス粉の乾燥したもの， ノイルを手切りしたものの混合物)をシリンダ上に連続 供給して実験したものである。

シリンダ、ドッファ䦎の接点から，この原料が噴出さ れる状況をピット內から眼で観察した綕果

1)シリンダのガーネットワイヤにひっかけられて いると推定されるものは, アンダ ケーシング內（1) 方 向）に運ばれる。

2)シリンダ表面に接して浮いていると見觉るもの は、アンダ ケーシング先端付近で(2)方问に進む。

3) ションダ表面より離れているものは，接点からて ンダケーシング迄の中間付近で乱れる・(瀜)

乥してそれらは (3)方向に落下するか，(4)方向に進文 ドッファ表面记っく。

4) 接点を出てすぐドッファに移ると思われるもの, すなわち、方向のあのは，关の速度が最も早いようで ある。

5) 按点を出てドッファに吸取られる (6) (5) (4) 万方の ものは，その順にその速度が弱くなるようである。

6) 煙実験その 2 の䣄線部の現像と，4）及び5 の 観察綕果とは，相一致するよ5亿教えられる。

\section{4 むすび}

メタッックカードについて第1 派の発表以来, カ一 ディング竹用の本質を究明するために，いろいろの实験 を計画し，実験中途のむの，開始したるの，あるいは準 備中のむの等，未だ結論を得たるのはなく，今回報告し

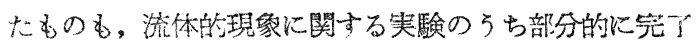
した事項である。

したがってすべて断片的矿なっだことを拈わびする次 第である。 